\title{
Serologic and Virologic Surveys on Feline Herpesvirus and Feline Calicivirus Infections in Cats for Experimental Use
}

\author{
Ken-ichi YAGAMI ${ }^{1 *}$, Toshinori FURUKAWA ${ }^{1,2)}$, and \\ Masanobu FUKUI ${ }^{1,2}$
Laboratory Animal Research Centre ${ }^{1)}$ \& Institute of Basic Medical Sciences ${ }^{2)}$, The University of Tsukuba, Sakura-mura, Niihari-gun, Ibaraki 305, Japan.

(Received 10 August 1984 / Accepted 2 February 1985)

\begin{abstract}
Serologic survey and virus isolation of feline herpesvirus (FHV) and feline calicivirus (FCV) were performed on cats used for research at the Laboratory Animal Research Centre, The University of Tsukuba, over the period from 1978 to 1981 . Of the 507 mature and immature cats, 4 months old or older, $102(20.1$ $\%$ ) had HI antibody against FHV and $412(81.3 \%)$ SN antibody against FCV. Some $23(16.2 \%)$ and $76(53.5 \%)$ kittens among 142 younger than 4 months had antibodies against FHV and FCV, respectively. Both the antibodies in kittens were considered to be maternally derived. The FCV antibody rate was especially high in cats weighing $2.5 \mathrm{~kg}$ (males) and $2.0 \mathrm{~kg}$ (females) or more, which were regarded as 8 to 10 months of age. An attempt was made to isolate the viruses from the oropharynx and conjunctiva of clinically healthy mature or immature cats and kittens. As the result, either one or both of the viruses were isolated from 31 of 75 mature and immature cats, and isolation rates of FHV and FCV were $6.7 \%$ and $36.0 \%$, respectively. On the other hand, no virus was detectable in 16 kittens.
\end{abstract}

Cats are often used for experiments in the fields of neurophysiology, pharmacology and ethlogy. They are mostly derived from dealers or a cat pound. They have an unknown history, and many of them die before actual use in experiments. Many fatal cases are known to suffer from some viral respiratory diseases.

Feline viral respiratory diseases are believed to be caused by feline herpesvirus (FHV) and feline calicivirus (FCV) [3]. These diseases are commonly observed in laboratory cat colonies, and they cause a major impediment in experiments using cats. Several researchers have reported isolations of $\mathrm{FHV}[2,10,20]$ and FCV $[6,9,18]$ from diseased cats in Japan. Goto et al. [5] ran a serologic survey for viruses in random-source laborator cats. They found that the prevalence of $\mathrm{FHV}$ and FCV antibodies was influenced by the age and locality of the animals.

The authors performed a serologic survey and virus isolation on stray and household cats which were introduced to our laboratory animal facility for experimental use, in order to determine the actual status of the viral infections and to know how to control them.

* Present address: Laboratory Animal Research Center, Kumamoto University Medical School, Honjo, Kumamoto 860, Japan. 


\section{Materials and Methods}

Animals: A total of 507 immature and mature cats, aged 4 months or older, were introduced to the Laboratory Animal Research Centre, The University of Tsukuba, over the period from 1978 to 1981. They were derived from four sources: a dealer (A) in Kanto district, a dealer (B) in Kinki district, the Central Pound (C) of Ibaraki Prefecture, and households (D) in the university area. One hundred and forty-two kittens younger than 4 months were also obtained from nearby households.

Sera : Serum samples from mature cats were taken within a few days after being obtained. Animals were housed independently in individual cages. Sera from kittens were obtained immediately after delivery and stored at $-70^{\circ} \mathrm{C}$. They were heated at $56^{\circ} \mathrm{C}$ for $30 \mathrm{~min}$. before use for serologic tests.

Viruses: KS-1 strain of FHV was previously isolated from the lung of a diseased cat in our laboratory [20]. C7301 strain of FHV [10] and F4 strain of FCV [18] were supplied by Prof. Dr. S. Konishi, University of Tokyo. KS-1 strain was used for FHV antibody checking, and C7301 strain was used in antiserum preparation for detection of $\mathrm{FHV}$.

Cell and cell culture: The cat ${ }^{S+l-}$ cell used for propagation of both viruses was supplied by Dr. N. Hirano, Iwate University. The cells were grown in Eagle's minimum essential medium (MEM) containing 10\% of newborn calf serum (NCS) and maintained in MEM supplemented with $1 \%$ of NCS. Penicillin G potassium and streptomycin sulfate were added to both media at final concentrations of 100 units $/ \mathrm{ml}$ and $100 \mu \mathrm{g} / \mathrm{ml}$, respectively.

Serologic tests: Hemagglutination-inhibition (HI) test was carried out by the microtiter method for detection of FHV antibody. The hemagglutinin was prepared according to the methods described by Mochizuki et al. [11], and phosphate buf- fered saline (PBS, pH 7.2) was used as a diluent for hemagglutinin and serum. Each $0.025 \mathrm{ml}$ of twofold serum dilutions was added with an equal volume of hemagglutinin containing 8 hemagglutination units. The contents were mixed and held at $23^{\circ} \mathrm{C}$ for $60 \mathrm{~min}$, and two volumes of $0.5 \%$ feline erythrocyte suspension in PBS were added. The test was read after incubation at $37^{\circ} \mathrm{C}$ for $2 \mathrm{hr}$. The $\mathrm{HI}$ titer was expressed as a reciprocal of the highest dilution inhibiting hemagglutination completely.

Serum-neutralization (SN) test for FCV was also carried out by the microtiter method. Maintenance medium without NCS was used as a diluent for serum and virus. To each $0.025 \mathrm{ml}$ of twofold serum dilutions $100 \mathrm{TCID}_{50}$ of FCV was added in an equal volume. After incubation in $5 \% \mathrm{CO}_{2}$ incubator at $37^{\circ} \mathrm{C}$ for 60 min, two volumes of growth medium containing $5 \times 10^{5}$ of cat $^{S+l-}$ cells were added to each well. The determination of cytopathogenic effect (CPE) was performed after incubation at $37^{\circ} \mathrm{C}$ for 4 days. The SN antibody titer was expressed as a reciprocal of the highest dilution inhibiting CPE completely.

Virus isolation: Swab samples were taken from oropharynx and conjunctiva for virus isolation. They were immediately suspended in Hanks' balanced salt solution (BSS) supplemented with $2 \%$ NCS and antibiotics, and centrifuged for $10 \mathrm{~min}$. at $3,000 \mathrm{rpm}$. The supernatant was used as inoculum to cell monolayers. Inoculated cell cultures were daily inspected for CPE for 7 days on incubation in $5 \% \quad \mathrm{CO}_{2}$ at $37^{\circ} \mathrm{C}$.

Viral isolates were passaged in cat ${ }^{S+l-}$ cell culture two or three times before use for further examination. The isolate which produced inclusion bodies in infected cells and showed hemagglutination activity in frozen and thawed cell material was regarded as $\mathrm{FHV}$-positive. In the same manner, the isolate in which infective activity remained after treatment 
with ethyl ether and filtration (100nm) was regarded as FCV-positive. FCV in the isolate which seemed to be positive for both viruses was separated by treatment with ethyl ether and filtration, and FHV by neutralization using antiserum against the FCV strain, respectively. Antiserum against FCV was prepared by intraperitoneal injection of Wistar rats with culture fluid. All isola tes and separated viral strains were identified by immunofluorescent staining with fluorescein isothiocyanate (FITC)-conjugated rabbit IgG against $\mathrm{C} 7301$ strain of $\mathrm{FHV}$ and $\mathrm{F} 4$ strain of $\mathrm{FC} \mathrm{V}$. The preparation of conjugated $\mathrm{IgG}$ and staining procedure were described in a previous report [20].

Statistical analysis: Statistical analysis was made using the $\mathrm{X}^{2}$ test.

\section{Results}

Antibodies against FHV and FCV in kittens : A total of 142 kittens' sera were submitted to $\mathrm{HI}$ test for $\mathrm{FHV}$ and $\mathrm{SN}$ test for FCV. Antibody titers of 1:4 or higher against FHV and FCV were detected in $23(16.2 \%)$ and $76(53.5 \%)$ kittens, respectively. Every serum collected from littermates showed the same results as all negative or positive. Age distributions of antibodies are shown in Table 1. Positive rates of $\mathrm{FHV}$ and $\mathrm{FCV}$ antibodies were $21.6 \%$ and $67.0 \%$ in the 0 - to 4 week-old group. They became lower in accordance with advancing age. Both antibodies were not demonstrated in all sera from 11- to 15-week-old kittens.

Antibodies against FHV and FCV in

Table 1. Age distributions of $\mathrm{HI}$ antibody against FHV and SN antibody against $\mathrm{FCV}$ in kittens

\begin{tabular}{|c|c|c|c|c|c|c|c|c|c|c|}
\hline \multirow{2}{*}{$\begin{array}{c}\text { Age } \\
\text { (in weeks) }\end{array}$} & \multirow{2}{*}{$\begin{array}{c}\text { No. } \\
\text { tested }\end{array}$} & \multicolumn{4}{|c|}{$\mathrm{HI}$ titers against $\mathrm{FHV}$} & \multicolumn{5}{|c|}{$\mathrm{SN}$ titers against $\mathrm{FCV}$} \\
\hline & & $<4$ & $\begin{array}{l}4 \\
8 \\
8\end{array}$ & $\begin{array}{c}16 \\
l \\
32\end{array}$ & $\geqq 4 \quad(\%)$ & $<4$ & $\begin{array}{l}4 \\
2 \\
8\end{array}$ & $\begin{array}{c}16 \\
32\end{array}$ & $\geqq 64$ & $\geqq 4 \quad(\%)$ \\
\hline $0-4$ & 88 & 69 & 11 & 8 & $19(21.6)$ & 29 & 36 & 21 & 2 & $59(67.0)$ \\
\hline $5-8$ & 23 & 20 & 2 & 1 & $3(13.0)$ & 8 & 10 & 5 & 0 & $15(65.2)$ \\
\hline $9-10$ & 16 & 15 & 1 & 0 & $1(6.3)$ & 14 & 2 & 0 & 0 & $2(12.5)$ \\
\hline $11-15$ & 15 & 15 & 0 & 0 & $0(0)$ & 15 & 0 & 0 & 0 & $0(0)$ \\
\hline Total & 142 & 119 & 14 & 9 & $23(16.2)$ & 66 & 48 & 26 & 2 & $76(53.5)$ \\
\hline
\end{tabular}

Table 2. Distributions of $\mathrm{HI}$ antibody against FHV and SN antibody against $\mathrm{FCV}$ in mature and immature cats derived from four sources

\begin{tabular}{|c|c|c|c|c|c|c|c|c|c|c|c|c|}
\hline \multirow[b]{2}{*}{ Sources* } & \multirow{2}{*}{$\begin{array}{c}\text { No. } \\
\text { tested }\end{array}$} & \multicolumn{5}{|c|}{$\mathrm{HI}$ titers against $\mathrm{FHV}$} & \multicolumn{6}{|c|}{ SN titers against $\mathrm{FCV}$} \\
\hline & & $<4$ & $\begin{array}{l}4 \\
2 \\
8\end{array}$ & $\begin{array}{c}16 \\
32\end{array}$ & $\begin{array}{c}64 \\
\text { ?े }\end{array}$ & $\geqq 4 \quad(\%)$ & $<4$ & $\begin{array}{l}4 \\
8 \\
8\end{array}$ & $\begin{array}{c}16 \\
? \\
32\end{array}$ & $\begin{array}{c}64 \\
128\end{array}$ & $\geqq 256$ & $\geqq 4 \quad(\%)$ \\
\hline A & 302 & 237 & 37 & 16 & 12 & $65(21.5)$ & 48 & 27 & 66 & 106 & 55 & $254(84.1)$ \\
\hline B & 94 & 72 & 19 & 3 & 0 & $22(23.4)$ & 6 & 11 & 24 & 29 & 24 & $88(93.6)$ \\
\hline $\mathrm{C}$ & 101 & 87 & 13 & 0 & 1 & $14(13.9)$ & 36 & 8 & 22 & 21 & 14 & $65(64.4)$ \\
\hline $\mathrm{D}$ & 10 & 9 & 1 & 0 & 0 & $1(10.0)$ & 5 & 0 & 0 & 4 & 1 & $5(50.0)$ \\
\hline Total & 507 & 405 & 70 & 19 & 13 & $102(20.1)$ & 95 & 46 & 112 & 160 & 94 & $412(81.3)$ \\
\hline
\end{tabular}

* A : Dealer in Kanto district, B : Dealer in Kinki district,

C : Pound in Ibaraki Prefecture, D : Household in Ibaraki Prefecture. 
Table 3. Relationship between body weights and positive rates of antibodies against $\mathrm{FHV}$ and $\mathrm{FCV}$ in mature and immature cats

\begin{tabular}{|c|c|c|c|c|}
\hline \multirow[b]{2}{*}{ Sex } & \multirow{2}{*}{$\begin{array}{c}\text { Body weight } \\
(\mathrm{kg})\end{array}$} & \multirow{2}{*}{$\begin{array}{l}\text { No. } \\
\text { tested }\end{array}$} & \multicolumn{2}{|c|}{ No. positive $(\%)$} \\
\hline & & & $\begin{array}{l}\text { Antibody } \\
\text { against FHV }\end{array}$ & $\begin{array}{l}\text { Antibody } \\
\text { against FCV }\end{array}$ \\
\hline \multirow{3}{*}{ Male } & $<2.5$ & 59 & $16(27.1)$ & $34(57.6)$ \\
\hline & $\geqq 2.5$ & 214 & $48(22.4)$ & $196(91.6)$ \\
\hline & Total & 273 & $64(23.4)$ & $230(84.2)$ \\
\hline \multirow{3}{*}{ Female } & $<2.0$ & 61 & $9(14.8)$ & $33(54.1)$ \\
\hline & $\geqq 2.0$ & 163 & $27(16.6)$ & $140(85.9)$ \\
\hline & Total & 224 & $36(16.1)$ & $173(77.2)$ \\
\hline
\end{tabular}

mature and immature cats: Sera were collected from a total of 507 mature and immature cats from 4 sources, and numbers of examined sera in sources A, B, C, and $\mathrm{D}$ were $302,94,101$, and 10 , respectively. Of these sera, $102(20.1 \%)$ had HI antibody against FHV and $412(81.3 \%)$ SN antibody against FCV (Table 2). Positive rates of $\mathrm{FHV}$ antibody were $21.5 \%, 23.4$ $\%, 13.9 \%$, and $10.0 \%$ in $\mathrm{A}, \mathrm{B}, \mathrm{C}$, and $\mathrm{D}$, and FCV antibody $84.1 \%, 93.6 \%, 64.4 \%$, and $50.0 \%$, respectively. The rates of both antibodies were higher in dealer cats ( $\mathrm{A}$ and $\mathrm{B}$ ) than in pound $(\mathrm{C})$ or house (D) cats. These differences were both significant at $\mathrm{p}<0.05$ in $\mathrm{FHV}$ antibody and $\mathrm{p}<0.01$ in $\mathrm{FCV}$ antibody.

The mature and immature cats were divided into 2 groups by body weight in each sex, and the relation between positive rate and body weight examined (Table 3 ). A highly significant difference was demonstrated in positive rates of FCV antibody between the two groups in body weight $(\mathrm{p}<0.05$ in both sexes). The rates were approximately $55 \%$ in the group with lower body weight, and reached nearly $90 \%$ in the group with higher body weight in both sexes. Such a tendency was not shown in the positive rate of FHV antibody. Moreover, a sexual difference was apparent in positive rates of both antibodies. Of 273 males, $64(23.4 \%)$ had FHV antibody and $230(84.2 \%)$ FCV antibody, while $36(16.1 \%)$ and $173(77.2 \%)$ of 224 females had these antibodies, respectively. These sexual differences in both the antibodies were significant at $\mathrm{p}<0.05$.

Isolation of viruses: An attempt was made to isolate the viruses from oropharyngeal and conjunctival swabs which were obtained from 75 clinically healthy mature and immature cats and 16 kittens during the quarantine. Thirty-seven cy topathogenic agents were isolated from 36 swab samples (31 oropharyngeal and 5 conjunctival swabs) of 31 mature and immature cats $(41.3 \%)$. Four FCV and one FHV strains were isolated from both oropharyngeal and conjunctival samples of same individuals, one each of the FHV and FCV strains from one cat, so 31 cats were positive for these viruses as shown in Table 4. Isolation rates of the viruses in animals from three sources, A, B, and C, were $41.2 \%, 25.0 \%$, and $48.3 \%$, respectively. These differences according to sources, however, were not significant. Among the 37 agents isolated, 5 were identified as FHV and 32 had FCV characteristics. In one cat both viruses were isolated, all the rest were infected only with either of the viruses ; $26(34.7 \%)$ were positive for $\mathrm{FCV}$ and $4(5.3 \%)$ for FHV. On the other hand, no viruses were detected in 16 kittens from neighboring households. These viruses were isolated from 31 of 75 oropharyngeal samples exami- 
Table 4. Virus isolation from clinically healthy cats

\begin{tabular}{|c|c|c|c|c|c|c|}
\hline \multirow{2}{*}{$\begin{array}{l}\text { Cats } \\
\text { (Age) }\end{array}$} & \multirow[b]{2}{*}{ Sources* } & \multirow{2}{*}{$\begin{array}{c}\text { No. } \\
\text { tested }\end{array}$} & \multicolumn{4}{|c|}{ No. of cats with agents $(\%)$} \\
\hline & & & FHV & $\mathrm{FCV}$ & $\begin{array}{l}\mathrm{FHV} \\
\dot{\mathrm{FCV}}\end{array}$ & Total \\
\hline \multirow{2}{*}{$\begin{array}{l}\text { Matures and } \\
\text { immatures }\end{array}$} & A & 34 & 3 & 11 & 0 & $14(41.2)$ \\
\hline & B & 12 & 0 & 3 & 0 & $3(25.0)$ \\
\hline \multirow[t]{2}{*}{$(\geqq 4 \mathrm{M})$} & $\mathrm{C}$ & 29 & 1 & 12 & 1 & $14(48.3)$ \\
\hline & Total & 75 & $\begin{array}{c}4 \\
(5.3)\end{array}$ & $\begin{array}{c}26 \\
(34.7)\end{array}$ & $\begin{array}{c}1 \\
(1.3)\end{array}$ & $31(41.3)$ \\
\hline $\begin{array}{l}\text { Kittens } \\
(4-16 w)\end{array}$ & $\mathrm{D}$ & 16 & 0 & 0 & 0 & $0(0)$ \\
\hline
\end{tabular}

* A : Dealer in Kanto district, B : Dealer in Kinki district, C : Pound in Ibaraki Prefecture, D : Household in Ibaraki Prefecture.

Table 5. Relationship between virus isolation and detection of antibodies against $\mathrm{FHV}$ and $\mathrm{FCV}$

\begin{tabular}{|c|c|c|c|c|c|c|c|c|c|c|}
\hline \multirow[b]{2}{*}{$\begin{array}{l}\text { Viruses } \\
\text { isolated }\end{array}$} & \multirow[b]{2}{*}{$\begin{array}{l}\text { No. of cats } \\
\text { having virus }\end{array}$} & \multicolumn{4}{|c|}{ HI titers against $\mathrm{FHV}^{*}$} & \multicolumn{2}{|c|}{$\mathrm{SN}$ titers } & \multicolumn{2}{|c|}{ against } & \multirow{2}{*}{$\begin{array}{l}\mathrm{FCV}^{*} \\
\geqq 256\end{array}$} \\
\hline & & $<4$ & $\begin{array}{l}4 \\
? \\
8\end{array}$ & $\begin{array}{c}16 \\
? \\
32\end{array}$ & $\geqq 64$ & $<4$ & $\begin{array}{l}4 \\
8\end{array}$ & $\begin{array}{c}16 \\
? \\
32\end{array}$ & $\begin{array}{c}64 \\
128\end{array}$ & \\
\hline $\mathrm{FHV}$ & 4 & 2 & 0 & 1 & 1 & 0 & 0 & 2 & 2 & 0 \\
\hline $\mathrm{FCV}$ & 26 & 20 & 5 & 1 & 0 & 5 & 1 & 3 & 10 & 7 \\
\hline $\mathrm{FHV} \cdot \mathrm{FCV}$ & 1 & 0 & 0 & 0 & 1 & 0 & 0 & 0 & 0 & 1 \\
\hline
\end{tabular}

* Assays in antibodies against FHV and FCV were carried out using KS-1 and $\mathrm{F} 4$ strains, respectively.

ned $(41.3 \%)$ and from 5 of 52 conjunctival ones $(9.6 \%)$, indicating the former site was more useful for detection of the viruses from cats. Moreover, only FCV was isolated from the conjunctiva of cats having both viruses in the oropharynx.

Relationship between virus isolation and antibody production against the tested strains (KS-1 and F4 strains) are shown in Table 5. Two of 4 cats positive in isolation of $\mathrm{FHV}$ and 5 of $26 \mathrm{FCV}$-positive cats were negative in detection of antibodies against corresponding viruses even though some seemed to demonstrate high antibody titers against each virus.

\section{Discussion}

The HI test against FHV used in this study was standardized by Mochizuki et al. [11]. The advantages were that inactivated virus could be used as a hemagglutinating antigen, and the results could be read rapidly and easily. This technique seemed to be useful for routine diagnosis of $\mathrm{FHV}$ infection in laboratory cats, though $\mathrm{SN}$ test has been mainly employed for serologic surveys on the infection up to the present time $[5,13,15,16]$. This is the first report in which HI test was used for serologic survey of $\mathrm{FHV}$ in cats.

It is generally believed that there exist some antigenic differences among FCV strains $[1,8,17,18]$. Povey $[14]$, however, claimed that FCV strains were essentially of a single serotype, though a few strains were regarded as serologic variants. This problem makes for complications in the 
analysis of the results of serologic tests for FCV infection. Since the F4 strain of FCV used in the present study reacted with 22 of 27 sera from cats having FCV, this strain was proved to be useful for detection of FCV antibody.

Povey and Johnson found FHV antibody at 50 to $75 \%$ and FCV at $82 \%$ of cats examined in Britain [13], and Studdert and Martin reported that respective antibodies were positive at $50 \%$ and 87 to $96 \%$ of cats in Australia [16]. On the other hand, Goto et al. [5] carried out serologic surveys on three random-source laboratory cat colonies in Japan, and recorded that 43 to $77 \%$ and 10 to $33 \%$ of cats in the 3 colonies had antibodies against two FCV strains used, and 20 to $86 \%$ were positive for antibody against FHV. Sagawa et al. [15] detected antibodies against FHV and FCV in $13 \%$ and $25 \%$ of house cats, respectively. Seropositive rates presented in our study were $20.1 \%$ for $\mathrm{FHV}$ antibody and $81.3 \%$ for FCV antibody, indicating that positive rate of FCV antibody was higher than that of FHV antibody, in accordance with other previous reports. Positive rate for FCV antibody in the present study was significantly higher than those reported by Goto et al. and Sagawa et al., who used different strains (No. 1 and Kyoritsu strains), and regarded $1: 8$ or $1: 5$ titers as seropositive limits. Because low SN titers against FCV may reflect antibodies against serological variants, the incidence of FCV antibody may vary according to the strain used and the seropositive limit.

The higher seropositive rates of both the antibodies were found in dealer cats than in the pound and house types, whereas no local difference was found between two groups of cats collected by dealers in Kanto and Kinki districts. Jensen et al. [7] carried out virus isolation from cats in rural and urban environments, and showed that prevalences of $\mathrm{FHV}$ and $\mathrm{FCV}$ were higher in rural area. They suggested that the difference was due to the frequency of contact between cats, because so-called stray cats were common in rural areas, but house cats in urban areas. Since dealers' animals tested in our study mainly consisted of stray cats, the difference of seropositive rates between dealers' cats and others was essentially in accord with the findings of Jensen et al.

Both the antibodies detected in kittens' sera were considered to be maternally derived, because they disappeared within about 10 weeks after birth. In mature and immature cats, the positive rate of FCV antibody was especially high in cats weighing $2.5 \mathrm{~kg}$ (males) and $2.0 \mathrm{~kg}$ (females) or more. Their body weights corresponded with those of cats aged 8 to 10 months or older. FCV infection might occur more frequently in these cats because of their extensive wandering habit due to sexual maturation. Such a tendency was not observed in FHV infection, though FHV also might spread in these cats in the same way. A reason for this phenomenon was considered to be the decline of FHV antibody titers in the majority of cats within several months after infection [12].

Wardley et al. [19] reported that FCV was isolated more frequently than $\mathrm{FHV}$; the former was positive in $8 \%$ of household pets, $24 \%$ of cats attending cat shows, and $41.5 \%$ of cats in two laboratory colonies, whereas the latter was isolated from only $1 \%, 1.75 \%$ and $0.4 \%$ of these cat groups, respectively. In the present study, FHV, FCV and both viruses were isolated from mature and immature cats at rates of 5.3 $\%, 34.7 \%$, and $1.3 \%$, respectively. This confirmed the findings by Wardley et al. Most of these cats were apparently in carrier states of the viruses, because they were all clinically healthy. Some of the virus-positive cats were negative in detection of antibodies agatnst the corresponding viruses. This inconsequence might be caused by antigenic differences between some FCV isolates and F4 strain used for FCV antibody checking and detection of the virus, since antigenic differences of FCV isolates have been known to be 
distinguished by SN test [14], but not by immunofluorescent staining [4]. On the contrary, only a single serotype is known to exist in many isolates of FHV. Two of FHV-positive cats having no detectable antibody might be in carrier states reexcreting the virus after decline of antibody titers. The majority of cats recovered from FHV infection become to be carriers and often re-excret the virus without clinical signs by a stressful stimulus such as a change of circumstances, parturition and administration of corticosteroids [3]. Besides, FHV antibody titers become to be undetectable within a short time after recovery [12]. Thus, virus isolation is considered to be more useful than clinical observation and serologic tests in detecting carriers of FHV and FCV, which are main sources of the viruses in laboratory colonies.

The laboratory use of such infected cats is unavoidable at present, since it is not easy to obtain microbiologically controlled laboratory cats (i. e., specific pathogen free cats). Therefore, it is recommended that the mature and immature cats should be separated from kittens in the animal room, during handling and use for experiments. In addition, the former must be isolated individually to prevent contact infection in each other, and be used for short-term experiments, because they are possible sources of the virus infection. Thus the latter may be maintained without the virus infections even for long-term experiments.

\section{Acknowledgements}

The authors wish to thank Prof. Dr. S. Motoyoshi, Nippon Zootechnical College, for his valuable suggestion and criticism. They are also grateful to Prof. Dr. K. Yasuraoka, Director of the Centre, for his encouragement and support.

\section{References}

[1] Bittle, J. L., York, C. J., Newberne, J. W., and Martin, M. (1960). Serologic relationship of new feline cytopathogenic viruses. Am. J. Vet. Res., 21, 547-550.

[2] Doi, K., Kojima, A., Inami, Y., Yasoshima, A., and Okawa, H. (1975). Feline viral rhinotracheitis in Japan -Isolation of herpes type virus and pathologic picture. Jpn. J. Vet. Sci., 37, 281-292 (in Japanese with English summary).

[3] Gaskell, R. M., and Wardley, R. C. (1978). Feline viral respiratory disease : a review with particular reference to its epizootiology and control. J. Small Anim. Pract., 19, 1-16.

[4] Gillespie, J. H., Judkins, A. B., and Kahn, D. E. (1971). Feline viruses. XIII. The use of the immunofluorescent test for the detection of feline picornaviruses. Cornell Vet., 61, 172-179.

[5] Goto, H., Horimoto, M., Shimizu, K., Hiraga, T., Matsuoka, T., Nakano, T., Morohoshi, Y., Maejima, K., and Urano, T. (1981). Prevalence of feline viral antibodies in random-source laboratory cats. Exp. Anim., 30, 283-290.

[6] Hiraga, T., Arai, S., and Fujie, N. (1973). On the feline calicivirus infection-like disease. J. Vet. Med. (Zyui-Tikusan-Shinpo), 603, 15-18 (in Japanese).

[7] Jensen, M. M., Buell, D. J., and Mckim, R. M. (1977). Isolation rates of feline respiratory viruses in local cat populations. J. Small Anim. Pract., 18, 659-661.

[8] Kahn, D. E., and Gillespie, J. H. (1970). Feline viruses. X. Characterization of a newly-isolated picornavirus causing intersitial pneumonia and ulcerative stomatitis in the domestic cat. Cornell Vet., 60, 669-683.

[9] Kamizono, M., Konishi, S., Ogata, M., and Kobori, S. (1968). Studies on cytopathogenic viruses isolated from cats with respiratory infections. I. Jpn. J. Vet. Sci., 30, 197-206.

[10] Mochizuki, M., Konishi, S., and Ogata, M. (1977). Studies on cytopathogenic viruses from cats with respiratory infections. III. Isolation and certain properties of feline herpesviruses. Jpn. J. Vet. Sci., 39, $27-37$.

[11] Mochizuki, M., Konishi, S., and Ogata, M. (1977). Sero-diagnostic aspects of feline herpesvirus intection. Jpn. J. Vet. Sci., 39, 191-194.

[12] Povey, R. C., and Johnson, R. H. (1967). Further observation on feline viral rhinotracheitis. Vet. Rec., 81, 686-689.

[13] Povey, R. C., and Johnson, R. H. (1971). A survey of feline viral rhinotracheitis and feline picornavirus infection in Britain. J. Small Anim. Pract., 12, 233-247.

[14] Povey, R. C. (1974). Serological relationships among feline caliciviruses. Infect. Immun., 10, 1307-1314.

[15] Sagawa, T., Ogaki, T., and Fujie, N. (1979). Studies on feline calicivirus infection and feline viral rhinotracheitis. I. Distribution of antibodies and clinical signs of experimentally infected cats. J. Ved. Med. (Zyui-Tikusan-Shinpo), 690, 13-16 (in Japanese).

[16] Studdert, M. J., and Martin, M. C. (1970). Virus diseases of the respiratory tract of cats. I. Isolation of feline rhinotracheitis virus. Aust. Vet. J., 46, 99105 . 
[17] Studdert, M. J., Martin, M. C., and Peterson, J. E. (1970). Viral diseases of the respiratory tract of cats : Isolation and properties of viruses tentatively classified as picornaviruses. Am. J. Vet. Res., 31, 1723-1732.

[18] Takahashi, E., Konishi, S., and Ogata, M. (1971). Studies on cytopathogenic viruses isolated from cats with respiratory infections. II. Characterization of feline picornaviruses. Jpn. J. Vet. Sci., 33, 81-87.
[19] Wardley, R. C., Gaskell, R. M., and Povey, R. C. (1974). Feline respiratory viruses -their prevalence in clinically healthy cats. J. Small Anim. Pract., 15, 579-586.

[20] Yagami, K., Ando, S., Omata, Y., Furukawa, T., and Fukui, M. (1982). Studies on viral respiratory disease in laboratory cats. I. Isolation of feline herpesvirus and choice of proper disinfectant. Exp. Anim., 31, 27-35.

\section{実験用ネコにおけるネコヘルペスウイルスとネコカリシウイルス感染の 血清学的およびウィルス学的調査}

八神健一 ${ }^{11}$. 古川敏 紀 ${ }^{1,2)} \cdot$ 福井正信 ${ }^{1,2)}$

1）筑波大学動物実験センター

2) 筑波大学基礎医学系

1978-1981年に筑波大学動物実験センターへ, 実験用 として導入されたネコについて，ネコヘルペスウイルス (FHV) とネコカリシウイルス (FCV) の血清学的調査 およびウイルス分離を実施した。 4 力月以上の成体拉よ び末成体 507 頭中, 102䫓 (20.1\%) が FHV 抗体を保有 し，412 頭 (81.3\%) が FCV 抗体を保有していた。一 方，4 月月齢未満の幼齢個体では，142頭中 23 頭 (16.2 \%) が FHV 抗体を，76頭 (53.5\%) が FCV 抗体を保 有し, これらはいずれも母親からの移行抗体と考えられ た。また，FCV 抗体保有率と体重との関係を検討した ところ, 雄: $2.5 \mathrm{~kg}$, 雌 $: 2.0 \mathrm{~kg}$ を境とし, それ以上の
群で有意に高い保有率を示した $(\mathrm{P}<0.05)$ このことか ら， 8〜10 月月㱓で FCV 感染例が急激に増加すると考 えられた。

さらに, 臨床的に健康な成体75頭, 幼齢個体16頭の咽 喉頭, 眼結膜からウイルス分離を試み，31頭の成体から $\mathrm{FHV}, \mathrm{FCV}$ もしくは両ウイルスを分離した。分離率は FHV で6.7\%，FCVで36.0\%であった。幼齢個体から は，両ウイルスともに分離されなかった。

実験用ネコの導入時に, キャリア状態のネコが高率に 存在することは, ウイルス性呼吸器疾患を防御するうえ で注目すべきことである。 